Georgetown University Law Center Scholarship @ GEORGETOWN LAW

2020

Pandemic as Opportunity for Competence Restoration Decarceration

Susan A. McMahon

This paper can be downloaded free of charge from:

https://scholarship.law.georgetown.edu/facpub/2356

This open-access article is brought to you by the Georgetown Law Library. Posted with permission of the author. Follow this and additional works at: https://scholarship.law.georgetown.edu/facpub

Part of the Health Law and Policy Commons 


\title{
Pandemic as Opportunity for Competence Restoration Decarceration*
}

\author{
Susan A. McMahon** \\ People are dying. We urge immediate action by the Court. ${ }^{1}$
}

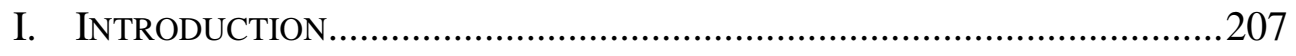

II. Competence Restoration Purgatory .........................................209

III. IMPACT OF COVID-19 ...................................................................21

A. Pandemic as Crisis ...............................................................212

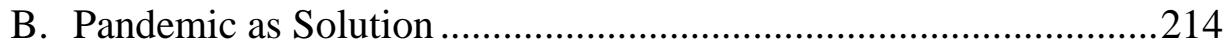

IV. NEXT STEPS AND DANGERS .........................................................215

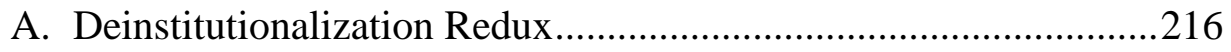

B. Retrenchment ...............................................................218

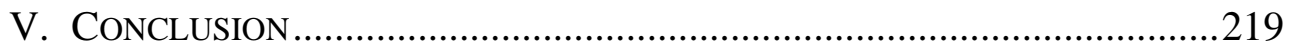

\section{INTRODUCTION}

Before the pandemic, a defendant found incompetent to stand trial was often stranded in jail for weeks or months as she waited for an inpatient bed to open at a psychiatric facility. ${ }^{2}$ While there, she usually received no

* This paper was published in December 2020 during the COVID-19 pandemic. All dates and time descriptions refer to the 2020-21 COVID-19 pandemic unless otherwise stated.

** Professor of Law, Legal Practice, Georgetown University Law Center. Many thanks to Erin Carroll, E. Lea Johnston, Jeffrey Shulman, Tom Spoth, and the participants in the Georgetown Law summer workshop series for their helpful feedback. I am also grateful to Elise Widerlite and the research librarians at Georgetown Law for their impeccable research assistance.

1. Status Notice at 1, In re Misdemeanor-Charged Defendants in Competency Evaluation or Restoration, No. 2020 CNC 000122, (D.C. Super. Ct. Apr. 9, 2020).

2. See, e.g., Second Amended Complaint at II 1, Trueblood v. Wash. Dep't of Soc. \& Health Servs., No. 14-cv-01178 (W.D. Wash. Sept. 12, 2014); Christie Thompson, Leila Miller \& Manuel Villa, Mentally Ill and Languishing in Jail, FronTLINE (June 6, 2019), https://www.pbs.org/wgbh/frontline/article/incompetent-to-stand-trial-languishing-in-jail/ [https://perma.cc/EU3U-6XZY]; Susan McMahon, Reforming Competence Restoration Statutes: An Outpatient Model, 107 GEO. L.J. 601, 609-10 (2019). 
treatment, her mental health deteriorated, and she was astonishingly likely to be abused and neglected. ${ }^{3}$ She almost certainly came out of jail in a worse state than she was when she went in.

The pandemic has made this desperate situation even worse. Now that wait in jail is both longer, ${ }^{4}$ as many psychiatric facilities stopped accepting new patients as they dealt with outbreaks or imposed social distancing measures, and more dangerous. Jails have been the sites of some of the worst virus outbreaks in the country. ${ }^{5}$

The solution to this problem is simple: release defendants. There is no inherent magic to inpatient treatment that renders it superior to community treatment. Even if community treatment is unavailable - a common problem in many jurisdictions - it is far worse to keep a person found incompetent in jail, where she will likely decompensate, suffer abuse or neglect, and, now, be exposed to a pandemic, than to release her.

Pre-pandemic, judges rarely released defendants found incompetent to stand trial for two reasons. First, many competence restoration statutes default to the inpatient option; some even require it. ${ }^{6}$ Second, judges, like most people, harbor deep-seated fears of individuals with mental illness, and they are reluctant to release individuals who they suspect may be dangerous, even if that suspicion is founded on stigma instead of fact. ${ }^{7}$

But the pandemic has forced judges' hands, and some are opting to release individuals who would have been slated for inpatient care and extended jail waits pre-COVID-19. In the District of Columbia, thirty-five people in competence proceedings were released. ${ }^{8}$ In Washington, a man charged with robbery was ordered to inpatient treatment; after he waited over three months

3. E.g., McMahon, supra note 2, at 613-17.

4. See Christie Thompson, For Mentally Ill Defendants, Coronavirus Means Few Safe Options, MARSHALl PROJECT (May 15, 2020, 6:00 AM), https://www.themarshallproject.org/2020/05/15/for-mentally-ill-defendants-coronavirus-meansfew-safe-options [https://perma.cc/DS7W-FABW].

5. E.g., Lucy Tompkins, Maura Turcotte \& Libby Seline, "I Just Kind of Lost It": As Coronavirus Cases Soar, One Montana Town Reels, N.Y. TIMES (Oct. 22, 2020), https:/www.nytimes.com/2020/10/16/us/rural-jails-coronavirus-mountain-west.html

[https://perma.cc/3WDS-TN7Q] (noting that 300 detainees and staff had been infected in a jail designed to hold 365 people); Timothy Williams \& Danielle Ivory, Chicago's Jail Is Top U.S. Hot Spot as Virus Spreads Behind Bars, N.Y. TIMES (Apr. 23, 2020), https://www.nytimes.com/2020/04/08/us/coronavirus-cook-county-jail-chicago.html [https://perma.cc/6JB5-2E55].

6. McMahon, supra note 2, at 627-36; see also Marisol Orihuela, The Unconstitutionality of Mandatory Detention During Competency Restoration, 22 BERKLEY J. CRIM. L. 1, 22-23 (2017).

7. See Michael Perlin, On "Sanism," 46 SMU L. ReV. 373, 401-03 (1992).

8. See Order at app. A, B, In re Misdemeanor-Charged Defendants in Competency Evaluation or Restoration, No. 2020 CNC 000122 (D.C. Super. Ct. May 10, 2020). 
in jail for a transfer, a judge dismissed the charge. ${ }^{9}$ While these are certainly small numbers, they indicate an opportunity to experiment with the decarceration of individuals found incompetent to stand trial. As the pandemic drags on, and defendants found incompetent remain stuck in limbo, pressure to decarcerate may continue to mount.

Thus, while the pandemic has made the already egregious lag times for competence restoration treatment worse, it might also contain the seeds of a solution to this intractable problem. A crisis of this proportion might be the one thing that could shake the criminal justice system out of its assumption that defendants should be detained while they wait for an inpatient bed to open.

\section{COMPETENCE RESTORATION PURGATORY}

Even before the pandemic, the situation for individuals found incompetent to stand trial was bleak. Jillian White was sixty-four years old with a brain injury and history of theft when she allegedly stole some bronze bird statues and a patio umbrella from her neighbors and was arrested. ${ }^{10}$ At first, she was released pending trial. ${ }^{11}$ Then she was found incompetent. ${ }^{12}$ Despite her attorney's pleas for outpatient placement, a judge ordered her arrested so she could undergo treatment. ${ }^{13}$ But White was never transferred to the inpatient facility, and nearly three months after her arrest, she died by suicide in her jail cell. ${ }^{14}$

Jamycheal Mitchell allegedly stole snacks from a 7-Eleven and, after his arrest, he was found incompetent to stand trial. ${ }^{15}$ Four months later, he starved to death in his jail cell. ${ }^{16}$ Prison officials allegedly had denied him food,

9. David Kroman, COVID-19 Leading to Illegal Jail Stays for Inmates with Mental Illness, CRosscut (May 6, 2020), https://crosscut.com/2020/05/covid-19-leading-illegal-jail-staysinmates-mental-illness [https://perma.cc/XH65-8GAT].

10. Police Report at 4, 7, Pitkin Cnty. Sheriff, Deputy Report for Incident 19P014199 (July 18,2019 ) (on file with author).

11. Jason Auslander, Pitkin County Jail Inmate Died by Suicide Sunday Night, Sheriff Says, ASPEN TIMES (Nov. 4, 2019), https://www.aspentimes.com/news/pitkin-county-jail-inmate-diessunday-night-investigation-underway/ [https://perma.cc/5VJG-89LY].

12. Id.

13. Id.

14. Id.

15. Complaint at II 2, Adams v. Naphcare, Inc., 246 F. Supp. 3d 1128 (E.D. Va. 2017) (No. 2:16-cv-229), 2016 WL 2865121, aff'd in part, rev'd in part sub nom. Adams v. Ferguson, 884 F.3d 219 (4th Cir. 2018).

16. Id. at II 102. 
turned off the water to his cell, and failed to provide him with medication to treat his mental illness. ${ }^{17}$

After Isaac Lemelle was found incompetent, he waited nearly six months for a transfer to a mental health facility. ${ }^{18}$ During that time, he was locked down in the jail's psychiatric unit, where he was only allowed out of his cell for one hour each day and had no guaranteed time outdoors. ${ }^{19}$

These stories are not unusual. Pretrial detainees routinely wait in their jail cells for weeks, months, or even over a year before a competence restoration bed opens. ${ }^{20}$ They often deteriorate, suffer from abuse and neglect, or are placed in solitary confinement during that time. ${ }^{21}$

To end up in this competence purgatory, defendants must first be found incompetent to stand trial, meaning that they either cannot consult with their attorneys with a reasonable degree of rational understanding or do not understand the proceedings against them. ${ }^{22}$ Once a judge finds a defendant incompetent, all criminal proceedings cease until her competence is restored. ${ }^{23}$ In most cases, that restoration happens at an inpatient facility, usually a state-run hospital. ${ }^{24}$ But those hospitals do not have nearly enough beds to accommodate all the defendants found incompetent every year. ${ }^{25}$ Hence the lengthy delays.

In one 2017 survey, eleven states reported wait times of anywhere between a month to more than a year for transfer to an inpatient facility. ${ }^{26}$ Lawsuits challenged these delays, and many of those cases either settled or were decided in the plaintiffs' favor. ${ }^{27}$ Yet even those states with judicially

17. Id. at III 4-5, 7, 12-13.

18. Third Amended Complaint for Injunctive and Declaratory Relief at II 12, Ward ex rel. Bourliot v. Hellerstedt, No. 1:16-cv-00917 (W.D. Tex. Sept. 29, 2017).

19. Id. at II 78.

20. NAT'L Ass'n Of State Mental Health Program Dirs., Forensic Patients in State $\begin{array}{lllll}\text { PSYCHIATRIC HOSPITALS: } & \text { 1999-2016, } & \text { at } & \end{array}$ https://www.nasmhpd.org/sites/default/files/TACPaper.10.Forensic-Patients-in-StateHospitals_508C_v2.pdf [https://perma.cc/6LP2-9ZLG].

21. McMahon, supra note 2, at 613-17; see also Laura I. Appleman, Deviancy, Dependency, and Disability: The Forgotten History of Eugenics and Mass Incarceration, 68 DUKE L.J. 417, 468-70 (2018).

22. See Dusky v. United States, 362 U.S. 402, 402 (1960).

23. See Drope v. Missouri, 420 U.S. 162, 171 (1975) (a defendant found incompetent "may not be subjected to a trial").

24. NAT'L Ass'N OF StAte Mental Health Dirs., supra note 20, at 38, 47.

25. See id. at 48,50 .

26. See id. at 50.

27. See Trueblood v. Wash. Dep't of Soc. \& Health Servs., 101 F. Supp. 3d 1010, 1022 (W.D. Wash. 2015) (finding seven days to be the "maximum justifiable period of incarceration"); Or. Advocacy Ctr. v. Mink, 322 F.3d 1101, 1123 (9th Cir. 2003) (requiring transfer within seven days); Advoc. Ctr. for the Elderly \& Disabled v. La. Dep’t of Health \& Hosps., 731 F. Supp. 2d 
imposed limits on wait times continue to see delays in treatment. Washington alone has been fined more than $\$ 83.4$ million and twice been held in contempt for its failure to adhere to a judge's order restricting wait times. ${ }^{28}$

These long waits can end tragically. Since 2010, at least 404 people with a mental health condition have died in America's jails. ${ }^{29}$ Suicides claimed the largest number of detainees; many of the other deaths resulted from abuse or neglect. ${ }^{30}$ For an individual living with a mental health condition, a jail setting is "at best, counter-therapeutic and, at worst, dangerous to [a detainee's] mental and physical well being." 31

\section{IMPACT OF COVID-19}

The pandemic has now made this purgatory not only lengthier, but also more dangerous. In the spring, hospitals stopped accepting transfers from

603, 627 (E.D. La. 2010) (requiring transfer within twenty-one days); Disability L. Ctr. v. Utah, 180 F. Supp. 3d 998, 1004, 1013 (D. Utah 2016) (denying motion to dismiss due process claim on behalf of incompetent defendants forced to wait as much as six months for admission to state psychiatric hospital); Terry ex rel. Terry v. Hill, 232 F. Supp. 2d 934, 938, 944 (E.D. Ark. 2002) (concluding that the six-month average wait in Arkansas for a defendant to be admitted to the state psychiatric hospital was "far beyond any constitutional boundary"); Settlement Agreement at II 2(a), Disability L. Colo. v. Bicha, No. 11-cv-02285 (D. Colo. Jul. 28, 2016) (requiring transfer within twenty-eight days); Second Interim Settlement Agreement at I[ 4, J.H. v. Dallas, No. 1:15cv-02057 (M.D. Penn. Jun. 15, 2017) ("parties will attempt to reach agreement on maximum allowable wait time").

28. Martha Bellisle, After Paying \$83 Million in Fines, Washington Settles Jail MentalHealth Lawsuit, SEATTLE TIMES (Dec. 12, 2018, 4:27 PM), https://www.seattletimes.com/seattlenews/judge-oks-settlement-in-case-against-washington-state-over-delays-in-mental-

competency-services/ [https://perma.cc/J92U-EAJM]; see also Allison Sherry, State Agrees to $\$ 10$ Million in Fines, Overhaul of How It Handles Mentally Ill in Jail, CPR NEWS (Mar. 16, 2019), https://www.cpr.org/2019/03/16/state-agrees-to-10-million-in-fines-overhaul-of-how-it-handlesmentally-ill-in-jail/ [https://perma.cc/F64M-7J9D] (describing Colorado's failures to abide by previous settlement agreements).

29. The true total is likely far higher because jurisdictions do not keep track of this statistic. To calculate this number, investigative reporters compiled a database of jail deaths based on public records. Gary A. Harki, Horrific Deaths, Brutal Treatment: Mental Illness in America's Jails, Virginian-PILOT (Aug. 23, 2018, 11:31 https://pilotonline.com/news/local/projects/jail-crisis/article_5ba8a112-974e-11e8-ba17b734814f14db.html [https://perma.cc/SP3K-TS8P].

30. Id. (noting that $44 \%$ of the deaths were suicides and many of the deaths were "under horrific circumstances").

31. Jamie Fellner, A Conundrum for Corrections, a Tragedy for Prisoners: Prisons as Facilities for the Mentally Ill, 22 WASH. U. J.L. \& POL'Y 135, 139 (2006); see also RAM SUbramanian ET AL., VERA InSt. OF JUSTICE, INCARCERATION's Front DOOR: THE MisuSE OF JAILS IN AMERICA 12 (2015), http://www.safetyandjusticechallenge.org/wpcontent/uploads/2015/01/incarcerations-front-door-report.pdf [https://perma.cc/MY7Q-NH7Y] ("Characterized by constant noise, bright lights, an ever-changing population, and an atmosphere of threat and violence, most jails are unlikely to offer any respite for people with mental illness."). 
jails because they sustained their own COVID-19 outbreaks or had a wellfounded fear of a new transfer instigating one. While many of those transfers have resumed, backlogs continue, and detainees who used to wait weeks for a placement are now told that no beds will open for months. And while they wait, they remain trapped in close quarters with other detainees, exposed to the virus in places that have incubated some of the worst outbreaks in the country.

Yet the severity of the crisis could lead toward decarceration as a solution. Because of the pandemic, jail populations have dropped, and judges have even released a handful of defendants found incompetent to stand trial. The moment has made possible a wholesale rethinking of whom we jail and why, which could result in a solution to the long-standing problem of mental health incarcerations.

\section{A. Pandemic as Crisis}

Jails and prisons overwhelmingly populate lists of COVID-19 clusters, far more so than nursing homes or meatpacking plants. As of July 25th, the worst cluster in the country was at the Marion Correctional Institution in Marion, Ohio, where 2,443 people were infected.$^{32}$ That same day, Harris County jail in Texas had 1,913 cases of COVID-19. ${ }^{33}$ Over 100,000 people in correctional facilities have contracted the virus. ${ }^{34}$ At least 802 inmates and correctional officers have died..$^{35}$

This should be no surprise, as it is almost impossible to social distance in a correctional facility. The ACLU described the situation elegantly in its complaint suing a federal detention facility for release of prisoners:

[I]magine if someone sick with COVID-19 came into your home and sealed the doors and windows behind them. That is what the Oakdale federal detention centers have just done to the over 1,800 human beings currently detained there, where a COVID-19 outbreak is rampant, social distancing is impossible, and no one detained can leave. ${ }^{36}$

32. Covid in the U.S.: Latest Map and Case Count, N.Y. TIMES (July 25, 2020), https://www.nytimes.com/interactive/2020/us/coronavirus-us-cases.html [https://perma.cc/25AU-JP8M].

33. Id.

34. Id.

35. Id.

36. Petition for Writ of Habeas Corpus, Injunctive, and Declaratory Relief at 1, Livas v. Meyers, No. 1:20-cv-00422 (W.D. La. Apr. 6, 2020) (footnote omitted). 
At the same time, state mental health facilities, where most competence restoration occurs, halted transfers from jails. ${ }^{37}$ The hospitals often became hotspots themselves. An outbreak at one New Jersey hospital resulted in 194 patients sickened and twelve dead. ${ }^{38}$ One news organization found that at least 1,450 cases of COVID-19 were associated with mental health facilities across twenty-three states and Washington, D.C. ${ }^{39}$

But these hospital shutdowns left individuals found incompetent stranded in jails, stuck with no treatment and no safe place to go. In June, Illinois had ninety-two defendants on a waitlist for admission for inpatient care. ${ }^{40}$ In Colorado, the waitlist for competence restoration treatment doubled in midApril. ${ }^{41}$ In Washington, estimated wait times increased by three months. ${ }^{42}$

In addition to the simple fact of the waits themselves and the damage they inflict on those with mental illness, lockdown protocols at many correctional facilities have kept inmates stuck in the jails in a form of solitary confinement. ${ }^{43}$ This, despite the fact that individuals with mental health conditions are particularly susceptible to the mental health harms solitary confinement inflicts. For prisoners with mental illness, placing them in isolation is akin to "putting an asthmatic in a place with little air to breathe." 44 As one doctor testified, isolating prisoners in small cells for twenty-three hours a day intensifies any preexisting mental illness:

Prisoners who are prone to depression and have had past depressive episodes will become very depressed in isolated confinement. People who are prone to suicide ideation and attempts will become more suicidal in that setting. People who are prone to disorders of mood, either bipolar ... or depressive[,] will become that and will have a breakdown in that direction. And people who are psychotic in any way ... those people will tend to start losing touch with reality because of the lack of feedback and the lack of social

37. See, e.g., Edith Brady-Lunny, State COVID-19 Orders Keep Mentally Ill Inmates in Jail, WGLT (Jun. 25, 2020), https://www.wglt.org/post/state-covid-19-orders-keep-mentally-illinmates-jail\#stream/0 [https://perma.cc/UM5B-VEDX].

38. Thompson, supra note 4.

39. Id.

40. Brady-Lunny, supra note 37.

41. Thompson, supra note 4.

42. Id.

43. Joseph Shapiro, As COVID-19 Spreads in Prisons, Lockdowns Spark Fear of More Solitary Confinement, NPR (June 15, 2020, 4:53 PM), https://www.npr.org/2020/06/15/877457603/as-covid-spreads-in-u-s-prisons-lockdowns-sparkfear-of-more-solitary-confinemen [https://perma.cc/7XKG-C5JA].

44. Madrid v. Gomez, 889 F. Supp. 1146, 1265-66 (N.D. Cal. 1995) (finding solitary confinement constitutes cruel and unusual punishment for prisoners living with mental health conditions). 
interaction and will have another breakdown, whichever breakdown they're prone to. ${ }^{45}$

The situation was desperate before the pandemic began. But with both increased wait times and use of solitary confinement-like techniques, not to mention the risk of sickness and death from COVID-19, things have gotten far, far worse.

\section{B. Pandemic as Solution}

Yet amid this grim news are signs of hope. The emergency situation has led to rapid and large reductions in jail populations; the typical jail reduced its population by more than thirty percent between March and May. ${ }^{46}$ These reductions have achieved in a matter of months what reformers have been attempting for decades. As one public defender said, "This moment has flipped the script on mass incarceration ... It's laid bare that caging huge swaths of our society isn't necessary — it's just convenient." 47

Nowhere is that more true than with defendants living with mental health conditions. For those found incompetent to stand trial, judges have been known to jail defendants pending restoration, even if the defendant poses no public safety risk, and even if the defendant had previously been released on bail. ${ }^{48}$

Nonetheless, massive reductions in jail populations have benefitted those found incompetent to stand trial in two ways. First, when defendants are released, space is freed up within the facility to better allow for social distancing. Even if defendants found incompetent to stand trial are not among those released, they face less risk of contracting the disease simply because the jail is emptier than it was pre-COVID-19.

Second, defendants found incompetent have been among those released, although their pending competence proceedings were often an additional hurdle for them to overcome to obtain release. In Washington, D.C., the public defenders service sought the release of fifty-seven misdemeanor

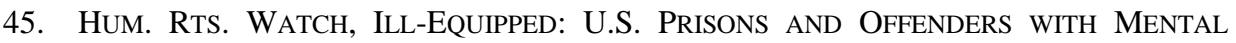
ILLNESS 152 (2003) (alteration in original) (quoting testimony of Dr. Terry Kupers in Jones'El v. Berge, No. 00-C-0421-C (W.D. Wis. 2001)).

46. Emily Widra \& Peter Wagner, While Jails Drastically Cut Populations, State Prisons Have Released Almost No One, PRISON POL'Y InITIATIVE (May 14, 2020), https://www.prisonpolicy.org/blog/2020/05/14/jails-vs-prison-update/ [https://perma.cc/C99BRAKE].

47. Sarah Stillman, Will the Coronavirus Make Us Rethink Mass Incarceration?, NEW YORKER (May 18, 2020), https:/www.newyorker.com/magazine/2020/05/25/will-thecoronavirus-make-us-rethink-mass-incarceration [https://perma.cc/9PAF-GC2S].

48. Orihuela, supra note 6,8-9. 
defendants who were being held in competence proceedings either at St. Elizabeth's Hospital or D.C. Jail. ${ }^{49}$ They argued that these defendants should be released both because they are stuck in competence purgatory with no trial date in sight and because of the risk to their lives and health in the institutional settings:

A deprivation of liberty under the circumstances present hereessentially an undetermined commitment driven toward a trial date that is no longer pending and a misdemeanor criminal proceeding that is entirely suspended-in and of itself would be problematic. The problem is multiplied by the fact that detention not only infringes on the individual's liberty, but exposes that individual to a virus that could have painful or deadly consequences. ${ }^{50}$

Thirty-five of those fifty-seven people were released; an additional eleven were released on their criminal charges but were remanded for civil commitment at St. Elizabeth's. ${ }^{51}$

Other anecdotal cases indicate a willingness on the part of judges to release defendants who would otherwise be stuck in jail for months on end while hospitals work through the backlog of defendants. One defendant charged with robbery waited in jail for nearly three months for a transfer to the state hospital. With no estimate for when a bed would open, the judge dismissed the charges. ${ }^{52}$ Another detainee was told he would not likely transfer until December. ${ }^{53}$ A judge called the delay "out of the question" and ordered him released..$^{54}$

After years of delayed treatment, it must now be clear that more beds will not open in psychiatric facilities. Even states under the watchful eye of the judiciary have consistently failed to keep up with the demand for competence restoration treatment. The solution is not to tinker with this mechanism. As the pandemic has shown, a better approach is to default to releasing defendants pending trial.

\section{NEXT STEPS AND DANGERS}

These decarceration trends are a silver lining in a very dark cloud. Many detainees are sick, many are dead, and, with spikes happening all across the

49. Order, supra note 8 , at 2 .

50. Omnibus Emergency Motion at 4, In re Misdemeanor-Charged Defendants in Competency Evaluation or Restoration, No. 2020-CNC-00122 (D.C. Super. Ct. Apr. 1, 2020).

51. Order, supra note 8, at app. A, B.

52. Kroman, supra note 9.

53. Id.

54. Id. 
country, these numbers will only increase. Even if they do not become sick, defendants found incompetent to stand trial are stuck in limbo in a dehumanizing place with little hope for recovery. And yet, the emptying of jails in response to the pandemic is the largest reversal in mass incarceration trends in recent memory. It presents an opportunity for jurisdictions to experiment with and move toward a non-carceral model.

But it is easy to fall back into past patterns. When it comes specifically to people with mental health conditions, two dangers loom: a repeat of the failures of deinstitutionalization and a quick return to the status quo.

\section{A. Deinstitutionalization Redux}

We have seen large releases of individuals with mental health conditions from confinement before. Beginning in the 1950s, deinstitutionalization took hold across the country. ${ }^{55}$ Mental hospitals emptied themselves of residentsdriven by the antipsychotic medication revolution, civil rights lawsuits, public opinion, and federal funding that covered treatment outside of the institutional setting ${ }^{56}$ _often with the thinking that the funds states would save on warehousing people who no longer needed it would follow those individuals into the community. ${ }^{57}$

That funding for community treatment centers never materialized. ${ }^{58}$ To make matters worse, in the 1980s, federal and state funding for housing and social security was cut drastically, leaving many vulnerable people without supports..$^{59}$

The conventional wisdom is that, as a result of these failures, those with mental health conditions who were released from institutions mainly wound up on the nation's streets and in its jails and prisons. There is some reason to

55. See, e.g., Gerald N. Grob, The Mad Among Us: A History of the Care of AMERICA's MENTALLY ILL 291 (1994).

56. See, e.g., id.

57. See, e.g., Robert Bernstein et Al., BAZElon Ctr. FOR Mental Health L., DIVERSION, NOT DISCRIMINATION: HOW IMPLEMENTING THE AMERICANS WITH DISABILITIES ACT Can Help Reduce the Number of PeOple with Mental Illness in JaIls 6 (2017) ("[D] einstitutionalization, as a policy or program, was supposed to be linked to and coordinated with the development of a comprehensive network of community mental health programs that were intended to replace hospital care and allow people with mental illness to live successfully in their communities. America failed to deliver on that promise ... . [O]nly fragments of what was intended to be a comprehensive system of community mental health services materialized." (footnotes omitted)).

58. Id.

59. See Samuel R. Bagenstos, The Past and Future of Deinstitutionalization Litigation, 34 CARdozo L. Rev. 1, 11-12 (2012); Brendan O'Flaherty, MaKing RoOM: The Economics of HOMELESSNESS 235 (1996). 
question this narrative; researchers have found that the population of those who lived in institutions and those who became incarcerated do not match up, ${ }^{60}$ and broader mass incarceration trends could instead account for some of the increase in populations with mental illness in jails and prisons. ${ }^{61}$ Yet, regardless of whether deinstitutionalization or mass incarceration was the driver, at least one cause of the mental health crisis in the nation's jails is likely the country's anemic mental health and welfare systems. ${ }^{62}$

That pattern of release-without-supports is continuing now, and we very well may see those released from jail fall into homelessness and arrest. But this should not be counted as a failure of release, if all we do is repeat the mistakes of deinstitutionalization. Instead, the current situation has provided an opportunity to begin to realize the unkept promise of community health centers and local supports. By investing in those individuals we have released; ensuring they have access to mental health care, substance abuse treatment, food, housing, and employment opportunities; and supporting them as they transition back into the community, society could experiment with a true model for mental health decarceration.

That said, the analogy between decarceration and deinstitutionalization does not perfectly track. For one, the populations are distinct: individuals found incompetent to stand trial are generally (but not universally) gravely disabled, while many (but not all) of those initially released from institutions may have lived with milder forms of mental illness. ${ }^{63}$ Outcomes may be far worse for decarcerated individuals than deinstitutionalized ones. On the other hand, the criminal justice system has tools at its disposal to encourage compliance with treatment regimes, like conditions of release, that were

60. See, e.g., Steven Raphael \& Michael A. Stoll, Assessing the Contribution of the Deinstitutionalization of the Mentally Ill to Growth in the U.S. Incarceration Rate, 42 J. LEGAL STUD. 187, 199-208 (2013).

61. See E. Lea Johnston, Reconceptualizing Criminal Justice Reform for Offenders with Serious Mental Illness, 71 FLA. L. REV. 515, 529 (2019) ("Harsh drug laws and the frequent cooccurrence of mental disorder and substance abuse likely account, at least partially, for the disproportionate justice involvement of individuals with serious mental illness.").

62. See Appleman, supra note 21, at 462-63 (arguing that deinstitutionalization has led to imprisonment of many disabled people in correctional facilities "[i]n large part ... because society has not been willing to devote enough resources to ensuring that deinstitutionalization works"). But see Johnston, supra note 61, at 529-30 (noting that studies have shown that changes in financing of community services have not "affect[ed] the probability of incarceration for individuals with mental illness").

63. See Fredrick E. Vars \& Shelby B. Calambokidis, From Hospitals to Prisons: A New Explanation, 102 CORNELL L. REV. ONLINE 101, 108 (2017) (noting that "many patients released before 1980 were older and stable enough to live in nursing homes"); $c f$. Raphael \& Stoll, supra note 60, at 190, 209 (noting that many of those released early were transferred to nursing homes and hypothesizing that deinstitutionalization "followed a chronologically selective path, with the least ill and perhaps the least prone to felonious behavior deinstitutionalized first."). 
unavailable to the institutions releasing former residents. ${ }^{64}$ While the affected populations and mechanisms of deinstitutionalization differ quite significantly from decarceration, one lesson is surely transferable: providing those released without any resources at all will almost certainly result in failure.

Yet even if states do not fund the programs that may lead to successful returns to communities, decarceration is still a goal worth pursuing. It is not at all apparent that forcible detention in a place that, at best, will worsen mental illness and, at worst, could lead to violent harm or death, is a superior option to homelessness or the other social ills that may befall those living with mental illness.

\section{B. Retrenchment}

Despite the many headlines blaring that "COVID Changed Everything," criminal justice may be slowly falling back into its mass incarceration patterns. A main driver of reductions in jail populations was fewer arrests and more pre-trial releases. In Washington, D.C., for example, the police department instituted a policy converting some crimes that previously would have resulted in arrest into citations. ${ }^{66}$ Other jurisdictions, like California, eliminated money bail for many crimes. ${ }^{67}$ Some judges and jail administrators released those serving short sentences for nonviolent offenses. ${ }^{68}$

64. I make no claim as to whether, normatively, these coercive measures are a superior approach. I only raise the point that this is a significant difference between the available tools of deinstitutionalization and the available tools of decarceration.

65. E.g., Shamila Batohi, Opinion, COVID-19 Has Changed Everything from Crime to Policy. Legal Systems Must Keep Up, GuARDIAN (Jun. 23, 2020, 1:00 AM), https://www.theguardian.com/global-development/commentisfree/2020/jun/23/covid-19-haschanged-everything-from-to-policy-legal-systems-must-keep-up [https://perma.cc/PH5RELET]; Coronavirus Will Change the World Permanently. Here's How, PolitiCo (Mar. 19, 2020, 7:30 PM), https://www.politico.com/news/magazine/2020/03/19/coronavirus-effect-economylife-society-analysis-covid-135579 [https://perma.cc/U3QF-HKV8].

66. See Amanda Michelle Gomez, To Reduce Lock-Ups, MPD Agrees To Cite More People During Coronavirus Emergency, WASH. CITY PAPER (Mar. 19, 2020), https://www.washingtoncitypaper.com/news/city-desk/article/21123137/to-reduce-lockupsmpd-agrees-to-cite-more-people-during-coronavirus-emergency [https://perma.cc/XK5MFVRX].

67. Darrell Smith, Judicial Council of California Approves $\$ 0$ Bail for Low-Level Suspects, $\begin{array}{llllll}\text { SACRAMENTO BEE } & \text { (Apr. } & \text { 8, 2020, } & \text { AM), }\end{array}$ https://www.sacbee.com/news/coronavirus/article241817606.html [https://perma.cc/66L6LQNZ].

68. E.g., Ricardo Torres-Cortez, 115 Clark County Jail Inmates Released To Prevent Virus Spread, LAS VEGAS SuN (Apr. 21, 2020, 8:30 PM), https://lasvegassun.com/news/2020/apr/21/115-clark-county-jail-inmates-released-virus-threa/ [https://perma.cc/R4U3-GJND]. 
But in many places, reductions in people entering jail were a matter of happenstance; in the early days of the pandemic, most people stayed in their homes, where they were less vulnerable to arrest. As the restrictions on movement have eased and courts have remained closed or backlogged, the jail populations began to creep back up. Harris County jail in Houston, Texas, for example, is nearly back to its pre-pandemic population, despite having one of the largest outbreaks of COVID-19 in the country. ${ }^{69}$ At the same time, the emergency efforts to empty jails that were so common in the early days of the pandemic have largely ceased. For example, Philadelphia police suspended low-level arrests at the start of the pandemic; on May 1, it resumed arrests for property crimes. ${ }^{70}$

One compilation of jail data for about 350 facilities shows the numbers inching back up. The population was at over 80,000 on March 16, as the pandemic took hold. ${ }^{71}$ At its low point on May 2, the population was $56,164 .^{72}$ By October 19, it was back above 70,000. ${ }^{73}$ This slow retrenchment promises to reverse the gains the emergency made possible.

\section{CONCLUSION}

The pandemic has simultaneously harmed defendants found incompetent to stand trial and revealed new possibilities for solving the long-standing problem of mental health incarceration. In a short period of time, many jurisdictions embraced jailing fewer people because jail posed serious risks to detainees' health.

Yet jail was nearly as dangerous to people with mental health conditions before the pandemic as it is now. Even after infections are no longer rampaging through correctional facilities, the goal of keeping defendants found incompetent to stand trial out of jail cells should remain. And if we seize the opportunity we now have to provide supports to defendants upon their release and experiment with alternatives to jail, we could meaningfully

69. Gabrielle Banks \& Samantha Ketterer, Harris County Jail Is Creeping Back Up to PreCOVID Capacity, Officials Warn, Hous. CHron. (Jun. 12, 2020, 7:43 PM), https://www.houstonchronicle.com/news/houston-texas/houston/article/Harris-County-Jail-iscreeping-back-up-to-15337247.php [https://perma.cc/XG47-4EFT].

70. Ellie Rushing \& Robert Moran, Philly Police Resume Pre-Coronavirus Arrest Procedures for Some Non-Violent Crimes, PHILA. InQUIRER (May 1, 2020), https://www.inquirer.com/news/philadelphia/coronavirus-philadelphia-police-arrests-theftburglary-covid-19-20200501.html [https://perma.cc/4QT4-QXMP].

71. Jail Data Initiative, PUB. SAFETY LAB, https://publicsafetylab.org/jail-data-initiative [https://perma.cc/T32N-GXCE].

72. Id.

73. Id. 
reform our system so that no future defendants are caught in competence purgatory. 